\title{
Physical, Political and Local Practice Factors as Barriers to Agricultural Development: A Case of the Kat River Valley, South Africa
}

\author{
C.N. Mbatha ${ }^{*}, 1$ and G.G. Antrobus ${ }^{2}$ \\ ${ }^{I}$ Department of Economics, University of South Africa, Pretoria, 0003, South Africa \\ ${ }^{2}$ Department of Economics and Economic History, Rhodes University, Grahamstown, 6040, South Africa
}

\begin{abstract}
The Kat River Valley, in the Eastern Cape of South Africa, provided a case study against which propositions of determinants of economic development were tested.

Physical location was found to matter in determining the level of development and economic leverage which Middle Kat farmers had compared to those downstream in accordance with Bromley's (1982) proposition. Physical location, however, was not a determining factor for farmers in the Upper Kat River who were the least developed. As predicted by Ostrom (1990), high transaction costs stemming from information asymmetries, selfish interests coupled with poor leadership, an unequal distribution of power and the flouting of formal agreements ensured the demise of a once successful Hacop project in the Upper Kat. Finally, Hirschman's (1960) much earlier line of argument was supported in that the nature of proposed development programmes and the compatibility with community values or 'self images' contributed to the lack of success of an externally initiated development effort.
\end{abstract}

The findings and conclusion serve an important lesson to economic researchers and decision makers not to duplicate policies for implementation in all geographical and social contexts on the basis of their success elsewhere.

Keywords: Development, agriculture, location, transaction costs, mental-images.

\section{INTRODUCTION}

More than five decades ago Hirschman [1] argued that the process of economic development was more complex than some economists would like to have us believe. The process did not follow a predetermined route, pattern or require a special ingredient as a catalyst. Often, it required an overhaul or evolution of social value systems in the manner well explained by Brinkman [2]. To achieve such an evolution, policy interventions would need to identify the most important factors that influence the development process and work towards enhancing or eliminating them (whichever was applicable) and in a coordinated manner. And most of all, any type of development, as argued by Hirschman [1] would first need to be understood and desired by local communities upon which it was introduced.

The Kat River Valley (KRV) in South Africa presents a case of three farming communities, with different economies, that are useful in illustrating the points of the foregoing propositions. The communities are located in the upper, middle and lower reaches of the valley. Using the works of Hirschman [1], Bromley [3], Ostrom [4] and to a lesser degree North [5], the paper proposes that geographical location, history, local politics and collective practices or makeup of local residents - in a coordinated fashion determine the state of economic development or deprivation in the context of the valley. Previous work by Mbatha and Antrobus [6] is reviewed and summarised regarding the

*Address correspondence to this author at the Department of Economics, University of South Africa, Pretoria, 0003, South Africa; Tel: +27836704287; E-mail: nhlanhla.mbatha@gmail.com middle and lower reach based community of farmers in Section 3. Hence, the current paper's discussion is mainly focussed on communities in the upper reaches.

The statements to be interrogated are as follows:

a) Bromley [3] proposed that geographical location (holding other factors constant) was important in determining differentiated economic states of community groups,

b) Ostrom [4] asserted that self interest, unequally distributed information and political power led to non cooperative behaviours and underdevelopment, and

c) Hirschman [1] argued that it was ultimately the nature of the proposed development and its degree of compatibility with local values that mattered the most for development to occur.

The KRV study - in the context of these positions - does support Hirschman's [1] statement that important factors work in a coordinated manner to determine how communities develop economically. For a greater likelihood of success at achieving economic growth and development, therefore, policy interventions have to be designed and implemented after identifying how important factors influence one another to either enhance or prevent economic progress. This was found to be especially true for the Northern or Upper sections of the Kat River Valley.

The ways in which the KRV data were gathered and analysed are explained in Section two. The literature on theoretical postulations, which are used as frameworks for the discussion, are reviewed in Section three. The valley is 


\section{River Basin}

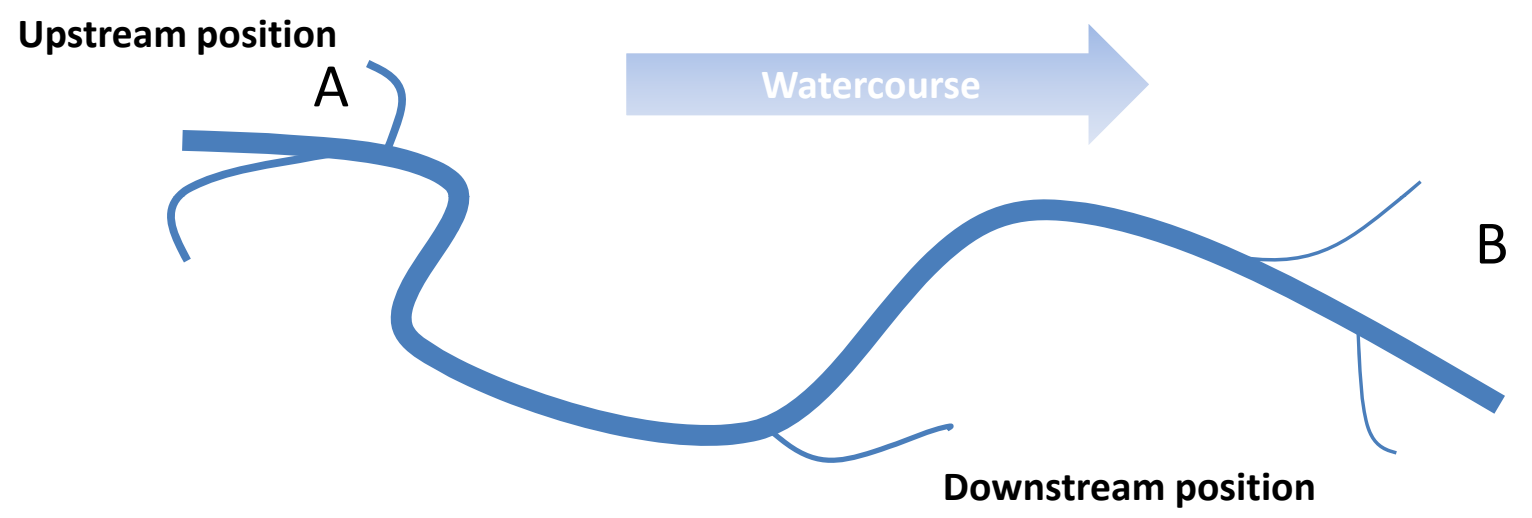

\section{Low uncertainty}

Fig. (1). A watercourse with individually abstracted water resources ${ }^{1}$.

\section{High uncertainty}

physically, socially and economically described in Section four. The discussion and theoretical analysis of the different sections of the KRV are presented in Section five. Concluding remarks with some recommendations are provided in Section six.

\section{THE RESEARCH METHODS}

Research methods that are espoused within the subdiscipline of Institutional Economics ${ }^{2}$ were used to collect and analyse data. "Theme mapping" was used to collect case study data from three distinct socio-economic sites [7, 8]. Supporting data was collected from, a) attending meetings of the KRV's Water Users' Association (WUA) from 2004 to 2005, and b) semi-formal and formal interviews with farmers from the different KRV sections. Commercial citrus farms and smaller irrigation schemes were visited over three years between 2004 and 2007 with a purpose to observe and document water resource abstraction methods from the river and to understand how water resources were used and stored on farm reservoirs. Since 2004 water policy workshops organised for large and small-scale water irrigators were attended (some facilitated) to gather data on the politics of water and land management from different sections of the valley. In addition, formal interviews with officials from the former provincial Departments of Water Affairs and Forestry $\left(\mathrm{DWAF}^{3}\right.$ ), Land Affairs (DLA) and Agriculture (DoA) were conducted between 2004 and 2006 with the aim to understand the formal national policy direction on the use of land and water resources. Secondary data from archival materials of the former Republic of Ciskei, KRV WUA,

\footnotetext{
${ }^{1}$ Uncertainty in the diagram refers to factors including both quantity and quality.

${ }^{2}$ In this sub discipline, institutions are the most important variables for economic analyses. They are variedly defined as cultural norms, customs, traditions, formal and informal, written and unwritten rules, etc., that govern social behaviours. Examples include written contracts, property rights laws, unwritten rules of social engagement, like etiquette, etc. [see 5, 7].

${ }^{3}$ Now called the Department of Water and Environmental Affairs (DWEA).
}

DWAF, DLA, etc., were consulted to gather historical data. During interviews, official and farmer respondents were allowed to orally recount their versions of historical events related to land and water use practices and politics. These were recorded and analysed in search of recurring themes or patterns. Lastly, data from scientific reports, e.g. the technical Kat Dam Operating Rules [11] and Water Quality Research documents [e.g. 10] were used to gather quantitative data. The collected data was then used to describe the general and specific economy and politics of the valley as well as to describe the physical characteristics of the basin.

\section{REVIEW OF SELECTED THEORY}

The factors influencing the general state of economic underdevelopment have been discussed from varied and often opposing point of views in the $20^{\text {th }}$ century. The main theoretical debates and their history are well illustrated in Brinkman [2]. The discussions pertaining specifically to the state of unequal economic development within river basins or water catchments have mostly been presented from institutional perspectives, for example Bromley [3]; Ostrom [4] and Vatn and Bromley [11]. The main debates and theories which can be applied to the KRV system have been selected here for a brief review. Throughout the discussion the limitations of some of the theoretical propositions are highlighted.

\subsection{The Physical Externality Model and Development}

Bromley [3] proposed that geographical location led to inefficiencies that promoted unequal economic growth among water users located along a linearly shaped water course, ceteris paribus. The water users would mainly be farmers who diverted water individually from its course as illustrated in Fig. (1), in the case for farmer A and B at upstream and downstream positions respectively. 


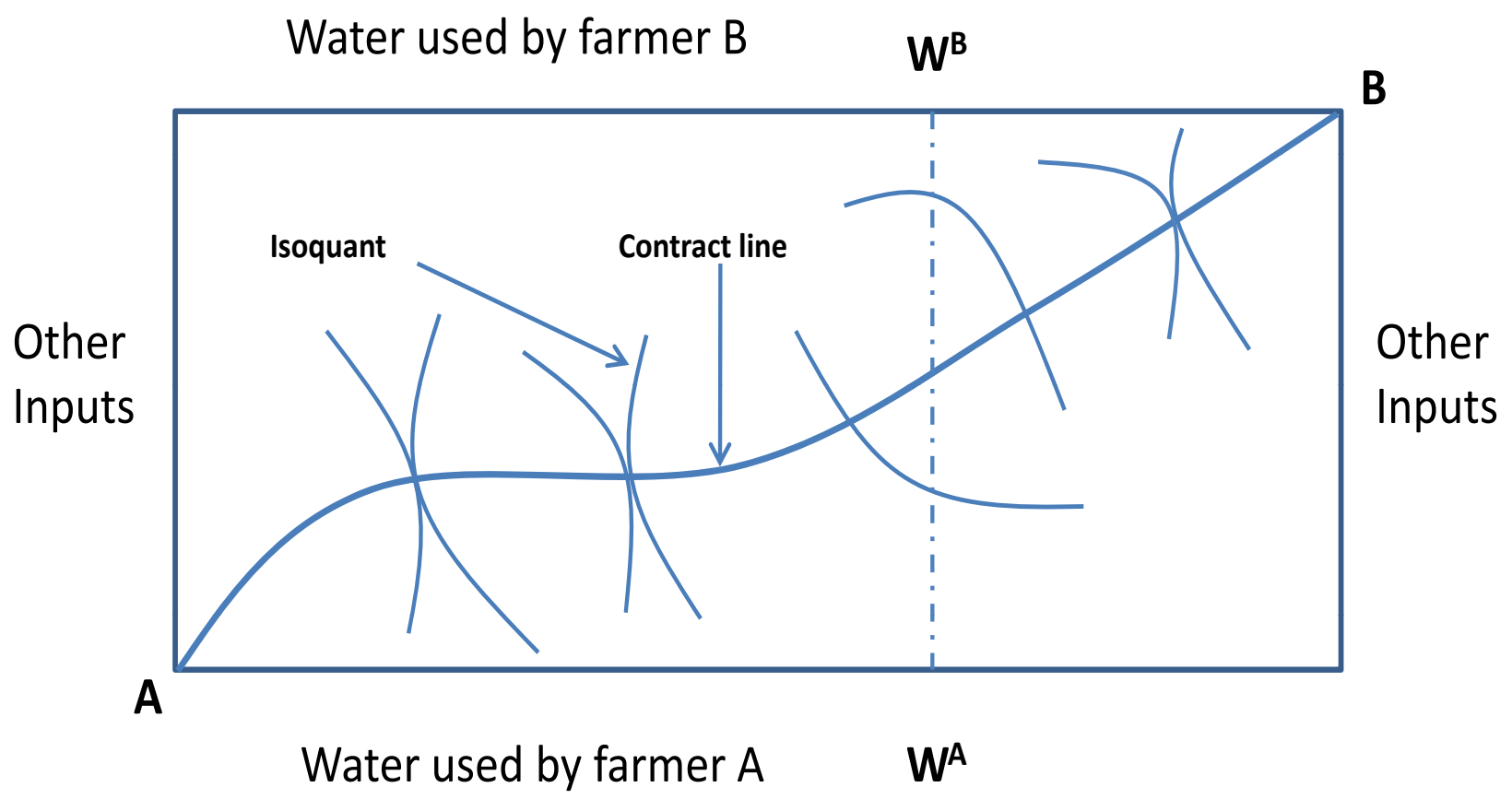

Fig. (2). Location water externalities. Source: [3].

In Bromley's [3] proposition, farmer $\mathrm{A}$ is favourably located for economic growth when compared to B, because the level of water available to B (as an input in his or her production) depends on how farmer $\mathrm{A}$ uses the water upstream. Farmer B then has to make his or her input mix decisions for the next production cycle in a relatively more uncertain environment when compared to A. The introduction of this additional uncertainty with respect to B's production is further explainable by the conventional production externality in the extension of the general equilibrium theorem. The Edgeworth box in Fig. (2) illustrates.

In the figure, the contract line depicts efficient water utilisation in production processes, regardless of initial resource distributions between farmers A and B. Any uncertainties in production cycles which face both farmers would most likely contribute to inefficient decision making. Instead of producing on the contract line, farmers tend to produce at points such as $\mathrm{K}$ and $\mathrm{J}$, outside the line. In case studies [3, 11] farmers in general have been found to underutilise available water inputs, and more so when they are located downstream. The underutilisation of this important resource has also meant that downstream located farmers tend to be smaller in size. The smaller farmers often produce at points like J in Fig. (2). Bromley's [3] illustration and his own evidence supports the proposition he makes that geographical location in physical environments which have been described cultivates both slow and unequal development. Evidence from the middle and lower reaches of Kat River Valley generally support the Physical
Externality model, with some institutional limitations. The application and limitation of the model was discussed by Mbatha and Antrobus [6] in the context of the middle and lower reaches of the valley.

\subsubsection{Findings from the Middle and Lower Kat Commercial Farmers}

In their discussion, Mbatha and Antrobus [6] advocated the investigation of local institutional arrangements in economic research by illustrating the limited applicability of general formal models in specific historical contexts. The predictive limitations, specifically, of the physical externality model was interrogated. The authors tested the proposition that the input use of citrus downstream farmers in the valley would be more inefficient and that these farmers would be less developed compared to their more upstream counterparts. They compared the production characteristics of farms in the middle reaches (upstream) $v s$ those in the lower reaches (downstream) to decide whether or not the relatively more upstream farmers were generally better off. The production characteristics they looked at included the number of farm reservoirs, weirs and pumps, boreholes (as proxies for water abstraction levels) as well as the size of land scheduled for water per farm and the size of land under citrus cultivation per farm. In 2004, it was found that only the farms in the middle reaches (upstream) had all the water scheduling rights and these farms also had more land under cultivation in total as shown in Appendix 1. The lower reach located farmers, on the other hand, had more land under cultivation per capita as well as more water abstraction and 
Table 1. The Herders' (or Prisoners') Dilemma

\begin{tabular}{|c|c|c|c|}
\hline \multicolumn{2}{|c|}{ PROFITS } \\
\hline Herders' Actions & Both Cooperate & One Defects/One Cooperates & Both Defect \\
\hline \hline Herder one & 10 unit profits & -1 or 11 unit profits & 0 unit profits \\
\hline Herder two & 10 unit profits & 11 or -1 unit profits & 0 unit profits \\
\hline
\end{tabular}

Adapted from [4, p4].

storage capital investments, such as in weirs, pumps, boreholes and reservoirs on average. The investment picture showed that the downstream farmers were faced with higher risks with respect to water availability mainly because of lack of scheduling; hence they invested in more efficient water use methods and alternative sources (e.g. reservoirs and boreholes). Moreover, more land was cultivated in total on upstream located farms. Therefore with respect to these variables the comparison between more upstream $v s$ downstream located farms in the basin supported the predictions of Bromley's [3] physical externality model. But still there remained questions needing answers with respect to cultivation levels on some farms in the lower reaches. For example, it was curious that the cultivation levels per farm were higher (by about 23\%) in the lower Kat even with alternative water sources and especially given the zero water assurances. An institutional interrogation showed that while downstream located farmers faced higher water availability risks, they were not restricted with respect to how much of their land they could cultivate. The upstream based farmers, on the other hand, were given a limit of how much land they could cultivate, restricted by their water scheduling rights. Hence, Mbatha and Antrobus [6] concluded that while upstream farmers enjoyed higher water assurances, total cultivation levels and other political leverage on water management issues they also faced other restrictions to develop land that came with historical water policies. Hence, although the physical externality model was useful in explaining some of the basin's important status quo, historical rights and policy factors gave further and more complete explanations regarding the economic relations between the middle lower basin farmer groups.

\subsection{Cooperation, Transaction Costs and Underdevelop- ment}

Using game theory and the prisoner's dilemma, Ostrom [4] illustrated how asymmetric distribution of information led to high social costs and pockets of underdevelopment. The model postulates that in some pasture (L) with two equally empowered and self interested herders (H1 and H2), but without an effective land management system, overgrazing (a probable feature of underdevelopment) is the most likely outcome. Such is the case even though both herders do know that if they both used more than their equal share of the pasture there would be overgrazing. Without each herder being able to know and guarantee that the other would only use their given share, an incentive exists for both to cheat on each other. However, the gains will be had only if only one of the two herders cheats. With self interested herders and lack of information about the other's actions, the model propositions that cheating would be the preferred and dominant behaviour, even with dire consequences for both herders. Table 1 illustrates the three possible community or social outcomes from all possible decisions that are likely to be taken by the herders. The table shows, a) how blind cooperation, although not a likely strategy, has the highest social benefits, b) how cheating by only one of the herders has higher private benefits for the cheater, and c) how cheating by both herders, which is the likely strategy, leads to overgrazing and has the highest social costs.

From the table, cooperation leads to a total of 20 unit profits for the community, while cheating by both herders leads to a total of zero unit profits. The incentive for cheating comes from the possibility of making higher private profits by each self interested herder (i.e. 11 as opposed to a potential 10 unit profits). The same reasoning on land resource use applies to the use of other natural resources like water from a watercourse which was described by Bromley [3].

Irrespective of which resources are being used, Olson [in 4, pp. 5-6) argued that cooperation or collective action would most likely become a preferred strategy if the community of users was small enough and there was an independent authority put in place that could act in their collective interest. The authority would have to be vested with some power to perform a monitoring function of the resource in use, distribute useful information and enforce penalties on cheaters. The costs of these functions would be borne by the community and they would reflect social transaction costs which would have to be subtracted from the potential total of 20 unit profits for the community (in Table 1, column 2). It follows then that cooperation and the preservation of commonly used resources (i.e. a level of higher development) could only be sustained if social transaction costs are not high enough to act as a disincentive for members to support the establish-ment and functioning of an independent management autho-rity. In that case, the costs would certainly not be higher than potential total profits (i.e. 20 units).

The proposition is for a transparent and effective political process at a microcosmic context for development to take place. North [5] presented a similar proposition about the burden of social transaction costs, however, in the establishment of effective political institutions for economic development at macroeconomic levels. When local land or water authorities cannot be established, or cannot be independent from private control by selected community members and they cannot have the ability to monitor and enforce commonly agreed upon rules, the resource in question would be mismanaged and used inefficiently and development as a whole would be undermined. 


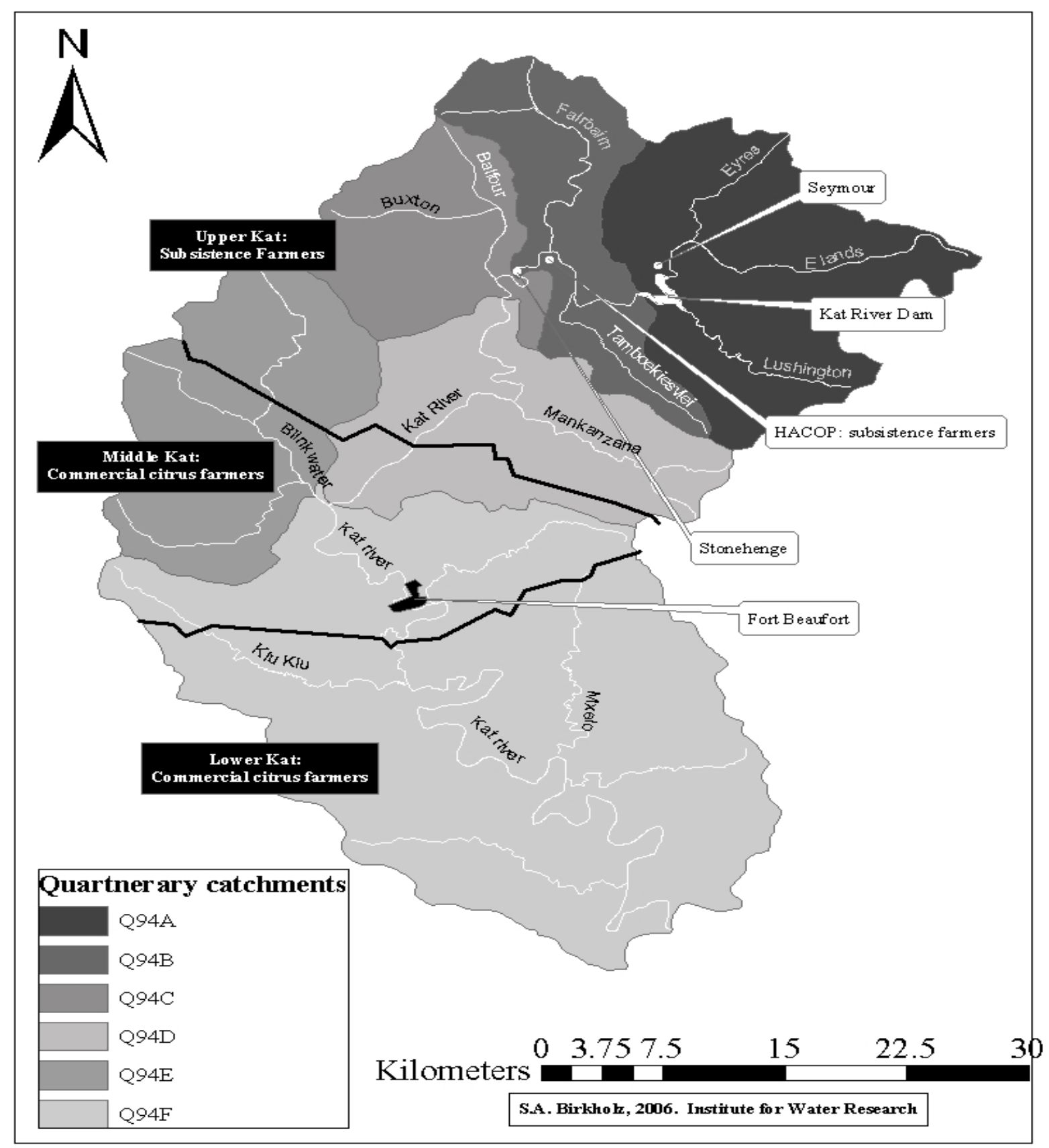

Map 1. The Kat River and its tributaries (alternative sources of water).

\subsection{The "Group-Focused Image of Change" and Development}

It has been argued from various quarters [2, 12 for instance] that the process of economic development entails the evolution of the whole social structure and its knowledge. ${ }^{4}$ This idea of social change partially led Hirschman [1] to remark that the "romanticised" communal community was actually its own enemy when it came to embracing the process of positive economic development. This was the case especially if that process required a change

${ }^{4}$ [13] deal with similar concepts of evolution, but with an emphasis on a
social management of natural resources as opposed to a purely social management of natural resources as opposed to a
technologically based or measured process of economic development. 
Table 2. Monthly Water Releases $\left(\mathrm{Mm}^{3}\right)$ from Kat Dam for Irrigation and Domestic Requirements

\begin{tabular}{|c|c|c|c|c|c|c|c|c|c|c|c|c|}
\hline \multicolumn{13}{|c|}{ Water Releases Per Month } \\
\hline Oct & Nov & Dec & Jan & Feb & Mar & Apr & May & Jun & Jul & Aug & Sep & Year's Total \\
\hline 0.73 & 0.92 & 1.81 & 2.52 & 1.50 & 0.91 & 0.78 & 0.64 & 0.54 & 0.49 & 0.57 & 0.61 & 12.06 \\
\hline \multicolumn{13}{|c|}{ Other Components Contributing to Total Annual Flows } \\
\hline \multicolumn{6}{|c|}{ Irrigation water requirement } & \multicolumn{7}{|c|}{10.04} \\
\hline \multicolumn{6}{|c|}{ Domestic water requirement } & \multicolumn{7}{|c|}{1.72} \\
\hline \multicolumn{6}{|c|}{ River losses } & \multicolumn{7}{|c|}{4.36} \\
\hline \multicolumn{6}{|c|}{ River flow below Kat Dam } & \multicolumn{7}{|c|}{4.06} \\
\hline
\end{tabular}

in social structure and a reshuffling of social positions. In such communities, "the total product having long been stationary, individual improvement could only take place at the expense of other members and of the cohesiveness of the group. Exceptional performance is therefore discouraged and penalised $d^{5}$ by a variety of social mechanisms of which the accusation of practicing witchcraft is best known" Hirschman [1]. Hence, members of a community with a "group-focussed image" of itself do not have aspirations to advance themselves at the expense of cultural values and others. This, Hirschman [1] argued was the reason why many externally initiated developmental projects simply fail to garner enough support to succeed in some developing countries. In a similar vein Eicher [14] presented evidence of trends of failed agricultural projects in African countries resulting from a mismatch between cultural norms and official policies or formal institutions. Similar evidence was found in the Kat River Valley.

\section{THE KAT RIVER VALLEY STUDY AREA}

The KRV is located in the Eastern Cape Province of South Africa. With a number of tributaries feeding into the Kat River (the main watercourse), the valley has three main sub-catchments and historical farmer settlement areas as already mentioned in the introduction and illustrated in Map 1. The Kat Dam is located in the Upper Kat, at the northeastern direction on the map and near the town of Seymour. It forms the main water storage for the valley.

In 2007, the Upper Kat (see the map) was the least developed section of the basin, with mostly subsistence farming taking place there. In the 1980s, this section was also part of the former black homeland of the Ciskei. The Middle and Lower sections were occupied by medium to large citrus growers and exporters. The patterns of human settlement and resource distribution found in the early 2000 s could be traced back to the $19^{\text {th }}$ century frontier wars between the native Xhosa against the Coloured people and British settlers [15]. In the early 1970s parts of the Upper KRV regions were transferred by the White South African government to the Ciskei homeland which was established in 1971. This meant that the White and Coloured citrus producers who were located in that region had to be removed and settled on land under the jurisdiction of the South African government, like the Middle and Lower sections of the basin $[4, \mathrm{p} 1)$.

\footnotetext{
${ }^{5}$ My emphasis.
}

\subsection{The Water Use Patterns}

In the 1990 s and early 2000 s it was commercial farmers, small irrigation schemes and household users who diverted and abstracted water from the Kat River watercourse. The water flowed from the Kat dam, which had a storage capacity of $24,892 \times 10 \mathrm{~m}^{3}$ and an assured yield of $11.88 \times$ $10 \mathrm{~m}^{3}$ per annum [17]. The capacity extended water security to approximately 1600 hectares of scheduled ${ }^{6}$ land over a three year period $[16,18]$. The monthly water release guide on volumes for all uses is presented in Table 2.

The table shows that while $10.4 \mathrm{Mm}^{3}$ were needed to meet the valley's annual scheduling requirements, 12.06 $\mathrm{Mm}^{3}$ were released. The indication is that an annual excess of less than $2 \mathrm{Mm}^{3}$ to irrigation requirements of unscheduled growers was incurred, while more than $4 \mathrm{Mm}^{3}$ constituted losses. Nevertheless higher water quantities were released in the early parts of the year, i.e. in January and February. Because citrus harvesting usually took place between the months of June and August, the lowest releases occurred during that time of the year.

\subsection{The Land Use Patterns}

Water requirements for irrigated citrus cultivation formed the largest share of abstracted water resources from the system. Other irrigation uses were insignificant, especially in the Upper Kat, where demand was for staple vegetables like cabbages, potatoes, etc. Depending on the total area of cultivated land (and) under irrigation on each farm or scheme, various amounts of water were abstracted. Table $\mathbf{3}$ presents patterns of agricultural land uses, by area and section of the valley [9].

By 2007 most of the tobacco cultivation had stopped, leaving citrus growing the biggest of commercial agricultural activities in the whole basin. This also meant that the majority of water abstraction was performed by the Middle to Lower KRV citrus growers. Farmers in the Upper KRV abstracted water for limited commercial use and for subsistence purposes. The land and water use patterns provide pictures of an economically depressed Upper KRV and commercially viable Middle and Lower KRV sections.

\footnotetext{
${ }^{6}$ Water scheduling is a system of riparian rights under the Water Act [19] where access to water rights was given on the basis of land under cultivation. After the rights were conferred to a farmer, s/he was not allowed to develop further land for irrigation. Nonetheless, the system is now gradually being replaced by an administrative system, still under implementation, as stipulated in the NWA [8].
} 
Table 3. Areas Under Cultivation in Each River Reach (ha)

\begin{tabular}{|c|c|c|c|c|c|c|}
\hline Section of the KRV by Reach (North to South Direction) & Citrus & Tobacco & Vegetables & Pastures & Other & Total \\
\hline $\begin{array}{l}1 \\
2 \\
3 \\
4 \\
5 \\
6 \\
7\end{array}$ & $\begin{array}{c}4 \\
264 \\
131 \\
246 \\
21\end{array}$ & $\begin{array}{c}185 \\
127 \\
47\end{array}$ & 37 & $\begin{array}{c}7 \\
37 \\
7\end{array}$ & 14 & \begin{tabular}{c|c|}
48 & \\
315 & 138 \\
246 & \\
206 & \\
127 & \\
47 &
\end{tabular} \\
\hline Total & 666 & 359 & 37 & 51 & 14 & 1127 \\
\hline
\end{tabular}

Source: [9].

The coming sections explain the likely origins of these patterns of unequal geographical development using the propositions made by Bromley [3]; Ostrom [4] and Hirschman [1].

\subsection{The History and Politics of the Valley}

Mbatha and Antrobus's [6] findings regarding the applicability of the physical externality model to Middle and Lower Kat commercial farmers were presented in Section 3.1.1. The case of the Upper KRV farmers, on the other hand, centres around the history of a prototypical African agricultural project (the Hertzog Agricultural Cooperative, Hacop), from which a number of narratives of successes and failures have been documented in past research reports and papers beginning in 1994. Most of the farmers and farming organizations found in the Upper KRV area have been associated with the Hacop initiative. At the project's inception in 1994, a great promise of success was displayed, to such an extent that some researchers described such success as uncharacteristic of typical projects in similar contexts [e.g. 20].

Black and Coloured Africans, some of whose forebears settled in the area during the 1900s, formed the main racial groups of the population of the villages. In 1996, the population of Hertzog alone was reported at 1000 individuals with 100 households. In 2004, the population of a total six Upper KRV villages was reported at over 5000 individuals. High unemployment rates were reported throughout the 1990s. In 1996 the official figure stood at $42 \%$ [19, p59], while in a 2004 research survey the rate was at over $60 \%$ (broad definition) [21]. Hence, the establishment of Hacop with its early successes was greatly welcome by residents as it provided employment opportunities as well as subsistence crops.

\subsubsection{Geographical Location}

When Hacop was established in 1994, it operated in the rural villages of Hertzog and Fairbain. These villages lie adjacent to each other in the Upper KRV as illustrated in Map 2.

The two villages contributed twenty-three and sixty hectares of irrigation land to the cooperative respectively ${ }^{7}$. Some forty hectares of land in Fairbain were also identified for future development. However, even though only two villages contributed land resources to the project, the residents of Phillipton (Northwest of Fairbain) were also invited to become

\footnotetext{
${ }^{7}$ These areas are far smaller and are incomparable to the area of land under cultivation in the Middle and Lower KRV sections as shown in Table $\mathbf{3}$.
}

part of the cooperative. These residents worked on land in Fairbain until 1996 when more land was acquired for irrigation in the Phillipton area itself [22].

\subsubsection{A History of Micro Developments and Challenges Since 1994}

Because no cultivation whatsoever took place in the village of Phillipton prior to 1996 and hence no land was immediately available to work on, the inclusion of this village into Hacop meant that the residents would travel daily to work plots in the Fairbain area. In the same year 1996, however, some land in Phillipton was leased to Hacop from a relative of one of the scheme members. This meant that the Phillipton unit would then operate as an autonomous body, with its own sub-committee. For some months, land from the three villages was used by the project. Ntsebenza [22] reported, however, that the Phillipton land lease was later withdrawn when a member whose relative had owned the land left the scheme. Hence, by the end of 2006 the Phillipton unit was disbanded. In addition, even though the Hertzog community members were at the forefront of the scheme's establishment, by as early as in 2006 the Hertzog unit was also out of operation [23]. The incidents indicate how much influence isolated individuals could wield in the general functioning, existence or even demise of the scheme.

Despite the fact that researchers wrote about the Hacop initiative as a great success [e.g. 20, 24], incidents of dictatorial tendencies in the leadership, community clashes over land restitution claims [25, 26], etc., contributed further to the demise of the project. Also, contrary to the guidelines of the scheme's own constitution (see Appendix 2), which provided for elected representatives in committees to stand only for a year, the chairperson from the scheme's inception never left the office. It was reported in interviews that several attempts to hold democratic elections to remove the chair had failed [23, 25]. To a greater degree the chairperson treated the project as though it was a personal business.

Signalling the scheme's financial mismanagement, it was reported that until 1999 Hacop had a single account into which all production profits were deposited as stipulated in the constitution. The constitution stated that "all proceeds will be deposited into the Hacop account, and transferred into plot holders' accounts on three predetermined dates annually, subject to provisions $6.4 ; 6.5 ; 6.6$ " (Appendix 2). However, the problems stemming from poor leadership and alleged financial irregularities meant that by 1999 separate bank accounts were opened by each village unit but without 


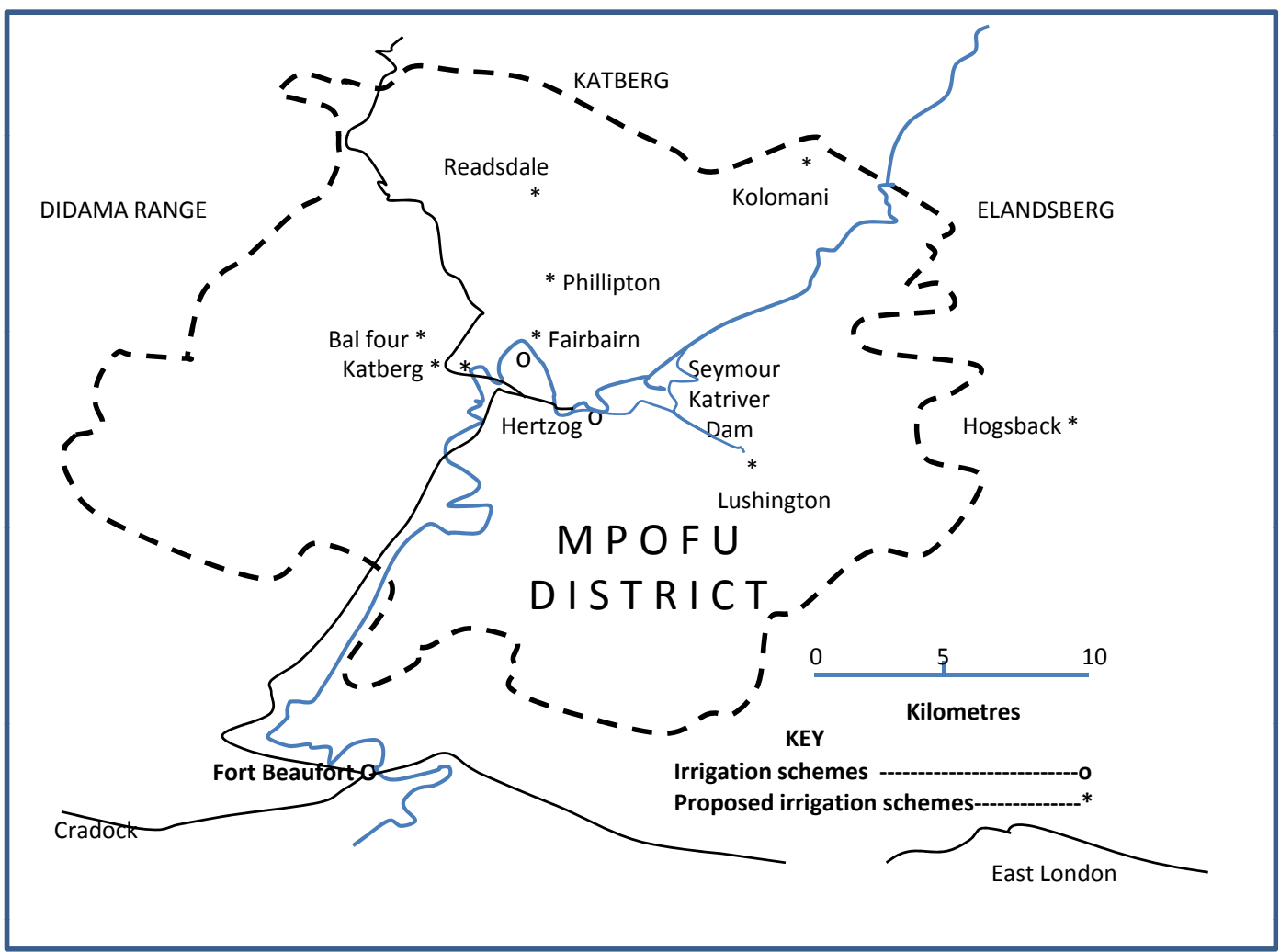

Map 2. Hacop villages in the Upper KRV.

any amendment to the constitution [23]. That further indicated an emergence of a breakdown in financial accountability that would characterise the scheme's operations from that period onwards.

In the setting up of the structure of Fairbain's management body, which is illustrated in Fig. (3), it is clear that once again the members disregarded explicitly the stipulated constitutional provisions.

The constitution stated, for instance, that only two representatives from each branch would be elected to form Hacop's umbrella committee. In practice, however, and as illustrated in Fig. (3), each of the three units had five members composing the fifteen member committee that was not even fully functional [25].

Information regarding the length of the land lease from the provincial Department of Land Affairs (DLA) was also conflicting. At a 2004 meeting in Fairbain, the chairperson of that unit asserted that the 1994 lease was only going to expire at the end of that year, as it was valid only for ten years. However, at a later workshop in 2006, farmers offered the opinion that the lease was valid for eleven years. The different types of information would signal a lack of transparency regarding the project.

Meanwhile, the DLA [16] had commissioned extensive research projects on land redistribution and restitution in the region that incorporated all the three villages. The findings included a revised Register of Land Title Deeds of 1998, and specific to Hertzog, was the 2002 Hertzog Agricultural Project Business Plan. The plan included discussions on using land previously leased to Hertzog for privately owned residential and agricultural land with communal land for grazing purposes, but without input from the scheme and without informing members of the new plans. From ongoing interviews, the scheme members were found to be vehemently opposed to private land use or ownership regimes. They preferred systems of collective land use in the same manner as when the scheme was initiated. The local communities also expressed negative sentiments against any new farmers in the area with land leases from the DLA, in its process to introduce a culture of individual private land rights [13]. The communities pointed out that the land leased to new farmers was not only under restitution claims but was also not being used optimally [22].

As a result of many of these reported incidents, challenges and perceptions, by 2007 the Hacop scheme was only functional in the Fairbain village. It then functioned without any kind of legal rights to land use from the DLA [27] and with default water access rights ${ }^{8}$. The majority of members were old and pensioners with limited technical skills and low potential to acquire new ones. The project no longer had an assigned extension officer from Micro Projects ${ }^{9}$, which had previously sustained it for more than ten years. Contrary to its own set of guidelines and procedures, operational meetings were seldom convened and membership had declined from close to a hundred to less than thirty [28]. Hence, the global picture of the whole KRV in 2007 depicted the Upper KRV area and farmers as the most economically depressed section and which did not compare to the Middle and Lower valley citrus growers.

\footnotetext{
${ }^{8}$ The water access rights would be valid until the New Water Law was implemented [28] .

${ }^{9} \mathrm{~A} n$ international Non Government Organisation.
} 


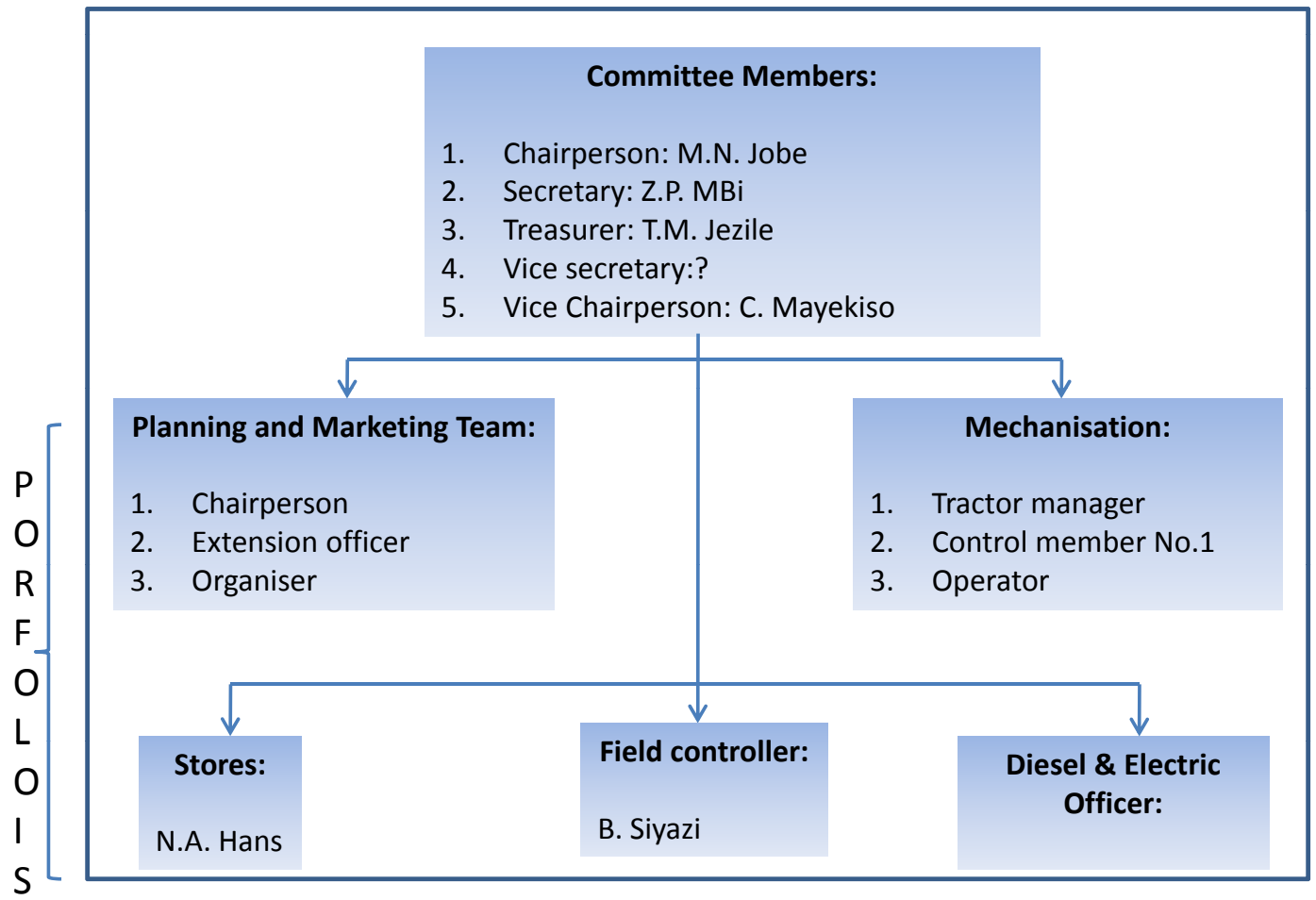

Fig. (3). Management structure 2005/6 Fairbain unit of Hacop. Source: [26].

\section{THE PHYSICAL, POLITICAL AND LOCAL PRAC- TICE AS OBSTACLES TO DEVELOPMENT IN THE KRV}

The discussion of the Middle and Lower KRV reaches by Mbatha and Antrobus [6] concluded that although physical geography was important in determining the relative degrees of economic development it did not provide a complete explanation.

The picture of resource ownership in the Upper KRV is vastly different. It was shown in Section 4 that the Upper KRV farmers, despite their favourable geographical position, were economically deprived. For instance, as members of Hacop the farmers did not own much land, commonly or privately. They had access to approximately a hundred hectares of land since 1994. Therefore their geographic location vs economic situation, especially, does not conform to Bromley's [3] postulations. Hence, a need exists for the discussion to explain the underdevelopment dynamics involving the Upper KRV growers $v s$ the rest in the basin. ${ }^{10}$

Physical location, other factors held constant, does of course matter with respect to whether or not an area would be relatively more developed, as discussed by Bromley [3] and illustrated by Mbatha and Antrobus [6] for the KRV. But when other more significant factors are at play, physical location, it appears has little to no influence as shown by the economic situation of the upper KRV. Among the important and influential factors, the century long history of the area, poor political leadership, suspicious perceptions regarding outsiders (new farmers) and negative sentiments towards some of the externally imposed policies (e.g. private land rights), etc., had a bigger negative contribution. This was in

\footnotetext{
${ }^{10}$ Mbatha and Antrobus [6] for a discussion and analysis of Middle and Lower KRV growers.
}

the form of high social transaction costs with respect to the management of Hacop and agricultural resources like land, and water to a lesser extent. The complete disregard by the DLA of pending land restitution court cases, local desires to practice communal ownership of land and leasing out of land to outsiders could have only contributed further to current and future social transaction costs in the valley.

In the game theoretic discussion of common land use by herders [4] it was illustrated and argued that high transaction costs stemming from an environment of information and power asymmetries encourage and sustain states of non cooperativeness which lead to underdevelopment. Although in its establishment and existence the Hacop scheme was externally supported by organisations including the DLA and the Micro Projects (which donated both equipment and services of an external officer), the cooperative was never independent from influence from other local forces. The first and only constitutionally elected chairperson of the project held much greater power compared to other members. The self interested actions of relatively more powerful farmers ${ }^{11}$ ensured that a lack of trust, non cooperation emerged and finally led to a partial breakdown of the project. By flouting constitutional guidelines (i.e. formal rules), the chairperson resisted elections, a decision that ultimately contributed to the formation of independently functioning but smaller village based units. The units had weaker leverage on external actors like the DLA. By 2006 only the Fairbain unit was operational. The Phillipton unit became dysfunctional soon after its inception in 1996, because a resourced member had left. Hence, the skewed distribution of resource ownership and political power both had a negative influence on the running of the scheme.

\footnotetext{
${ }^{11}$ For example the farmer connected to the owners of leased land in the Phillipton village.
} 
Important information regarding the founding and running of Hacop was not equally shared or understood by all members in the various units. As mentioned previously, the different members of the Fairbain unit had a different understanding of when the DLA's lease of 1994 would expire. While some believed it was to be in 2004 others thought it was the following year of 2005. The Land Affairs department insisted it was 2004 and that the lease would not be renewed thereafter $[6,27]$. Therefore different narratives emerged from various players leading to strategies, internally and externally proposed, that were futile because they were based on conflicting information.

The formal institutions that governed the project (e.g. the constitution) were constantly flouted by individual members and village unit structures. For example, the management structure (in Fig. 3) at Fairbain was not based on constitutional guidelines (Sec. 6, Appendix 2). That was further indication that there was limited trust put on the formally written rules, which supposedly formed the basis for the existence of the project. In Ostrom's [4] proposition, such factors would only have contributed to rising further the social transaction costs in the project's management.

The DLA's 2002 plans to reconfigure the land use and ownership rights from common access to private ownership in the Hertzog village was further indication of a mismatch between official policy vs local desires for common resource use and management. While the villagers preferred the renewal of the communal 1994 land lease, the government was introducing different rules for the game [29]. Clearly the villagers saw themselves as a "group" in Hirschman's [1] definition. They wanted to develop as a community of farmers, not as isolated individual land owners. As a group, they also resented in coming farmers with land leases from the DLA. Further, in a climate of disputed land restitution claims, which were ongoing across the whole country, it seemed unlikely that the government's efforts to introduce a different culture of land use, access and ownership would succeed without local opposition. Possibly the villagers feared that the individual acquisition of land rights by outsiders and locals would lead to an alteration of local power structures, which are described in Hirschman [1, p15]. This, for a group-focussed community would not be a preferable, supported or sustainable route to development. Based on Ostrom's [4] and Hirschman's [1] postulations, the Upper KRV section would most likely never experience further economic development within the prevailing conditions. The barriers to development in this sense would not only be physical, but also political and stem from conflicts between externally initiated rules against local practices.

\section{CONCLUDING REMARKS AND SOME RECOM- MENDATIONS FOR POLICY MAKERS}

There are several factors of varying importance that determine whether or not a location can and would develop economically. Bromley [3] proposed that geographical location and related institutions were important determinant factors. Ostrom [4] illustrated why and how self interest, unequally distributed information and political power would lead to noncohesive behaviours among users of common resources and how those would lead to a rise in transaction costs preventing local development from occurring. Hirschman [1] long argued that it was ultimately the nature of proposed development programmes and their compatibility (or lack thereof) with community values or practices that determined the potential success of externally initiated development efforts.

The discussion of the Kat River Valley provided a test for these statements. Mbatha and Antrobus [6] found that physical location mattered in determining the level of development and economic leverage which the Middle KRV located farmers had vis-à-vis those located in the Lower KRV sections. Physical location was, however, definitely not a determining factor for economic development when looking at the most upstream located farmer cases. The Upper KRV was not only the least developed section but had little future prospects especially given the some of the plans of the DLA [29].

In line with the framework presented by Ostrom [4], high transaction costs stemming from information asymmetries, self interests of resourced local farmers, coupled with poor leadership and the constant flouting of formal rules (e.g. the constitution) ensured the demise of the once reportedly successful Hacop project. By as early as 1996 a third portion of the project (i.e. the Phillipton unit) was defunct. By 2007, only the Fairbain unit was still in operation. Throughout the life cycle of the project the management structure was rendered ineffective with declining membership and land cultivation rates.

The KRV case illustrates that the process of development is of course complex. Often it is a number of factors working in coordination that determine whether or not development can and would take place. There is hardly a single factor that could be identified as one crucial and missing ingredient to be found for all geographical contexts as postulated by Hirschman [1]. In the KRV case, geographical location may have determined the relative success of Middle Kat farmers, while history, local politics, and the non-compatibility of community rules or practices with official plans contributed to social and economic failures as experienced in the Upper Kat. The findings and conclusion serve as an important lesson for economic researchers and policy makers not to duplicate policies for implementation in any geographical or social context, even if they were successful elsewhere. With the South African government still attempting to implement policies aimed at social transformation, especially with respect to the use of natural resources like land and water, the most important lesson from the discussion should lead to a complete abandonment of prescriptive (top down) policies. The implementations of programmes and legislation like the Land Redistribution for Agricultural Development [30] and the National Water Act [31] should account for and quantify the associated potential transaction costs that may arise stemming from incompatible local practices. In the case of water management, for example, the costs of running governance bodies could not be higher than potential benefits as proposed by Oslon [in 4, pp. 5-6] for a management authority. Depending on a comparison between estimated costs $v s$ benefits, the relevant public agencies would have to respectively evaluate their implementation of ongoing strategies with respect to rights to land and governing organisations for water resources.

\section{ACKNOWLEDGEMENTS}

The Water Research Commission (WRC) of South Africa is acknowledged for the financial support it provided for the research forming the basis for the article 


\section{APPENDIX 1}

\begin{tabular}{|c|c|c|c|c|c|c|}
\hline Enterprise & Reach & No. of on Farm Reservoirs & Scheduled Hectares of Land & Citrus Cultivation & Weirs and Pumps & Boreholes \\
\hline A & Middle & 4 & 337 & 285.7 & 8 & $\mathrm{n} / \mathrm{a}$ \\
\hline B & Middle & & 61 & 50 & 1 & $\mathrm{n} / \mathrm{a}$ \\
\hline $\mathrm{C}$ & Middle & 3 & 5 & 30 & 1 & 4 \\
\hline $\mathrm{D}$ & Middle & $\mathrm{n} / \mathrm{a}$ & 24.5 & 21 & $\mathrm{n} / \mathrm{a}$ & $\mathrm{n} / \mathrm{a}$ \\
\hline $\mathrm{E}$ & Middle & 1 & $\mathrm{n} / \mathrm{a}$ & 15 and 19 & 1 & 2 \\
\hline $\mathrm{F}$ & Middle & & 11.5 & 20 & 0 & $\mathrm{n} / \mathrm{a}$ \\
\hline G & Middle & 2 & $\mathrm{n} / 5$ & 0 & 0 & 2 \\
\hline Total & & 10 & 439 & 442 & 11 & 8 \\
\hline $\mathrm{H}$ & Lower & 3 & 0 & 111 & 2 & 1 \\
\hline I & Lower & $\mathrm{n} / \mathrm{a}$ & 0 & 0 & $\mathrm{n} / \mathrm{a}$ & $\mathrm{n} / \mathrm{a}$ \\
\hline $\mathrm{J}$ & Lower & $\mathrm{n} / \mathrm{a}$ & 0 & 66 & 2 & $\mathrm{n} / \mathrm{a}$ \\
\hline $\mathrm{K}$ & Lower & $\mathrm{n} / \mathrm{a}$ & 0 & 63 & $\mathrm{n} / \mathrm{a}$ & $\mathrm{n} / \mathrm{a}$ \\
\hline $\mathrm{L}$ & Lower & 3 & 0 & 36 & 2 & 1 of 3 is used \\
\hline Total & & 6 & 0 & 276 & 6 & 4 \\
\hline
\end{tabular}

\section{APPENDIX 2}

\section{The Hacop Constitution (Up to Section 6)}

\section{Name of the project}

1.1. The project will be called Hertzog Agricultural Co-operative, with understanding that it includes the following areas, which form part of this zone: Hertzog, Fairbain, Phillipton.

\section{Structure}

2.1. The project will be owned by individual plot holders

2.2. The plot holders will appoint a committee consisting of two representatives of each of the three communities as in 1.1., which will serve for one year.

2.3. Hacop will be affiliated to the Hertzog Reconstruction and Development Program (Hertzog R.D.P.)

2.4. Hertzog R.D.P. will on its turn be affiliated to Mpofu R.D.P.

\section{Status}

Hacop will be an Agricultural Community Project

\section{Aims}

Hacop will:

4.1. Educate and empower its members to operate a sustainable and economically viable agricultural operation on one hectare of land (per member?)

4.2. Put to optimum use all the available land in our area.

4.3. Cultivate an agricultural culture in our community.

4.4. Encourage and empower our people to improve their own living conditions.

\section{Objectives}

Hacop will:

Produce three crops per year

Repay all input costs after each crop

Generate a liveable income for each of its members

Follow a strict VIABILITY plan (6)

Empower each of its members to be:

Self-supporting.

Economically viable.

Job creators. 
(APPENDIX 2) contd.....

\section{Viability plan}

6.1. Production will be done according to a very carefully worked out plan, under the supervision of an experienced commercial farmer (amended to $=$ agricultural officer)

6.2 Will have a very strict and efficient administration

6.3 All the marketing will be done by the Management Committee

6.4. All proceeds will be deposited into the Hacop account, and transferred into plot holders' accounts on three predetermined dates annually, subject to provisions $6.4,6.5$, and 6.6 .

6.5. signatories to this account will be any two of the three signatories appointed by the committee (one from each area as in (1.1)

6.6. The proceeds will be administered by the administration of Hacop as follows:

6.6.1. All input costs will be re-imbursed.

6.6.2. $25 \%$ of balance will be put into Capacity Building Fund.

6.6.3. This account will only be used for capacity building and in the event of crop failure

6.6.4 In the event of the balance in this account exceeding R10000,00, the general meeting can, with two-thirds majority, decide to pay the excess to the plot holders as a bonus

6.6.5 50\% of balance will be transferred into the plot holders' account as a plotholders' dividend.

6.6.6 The remaining $50 \%$ will be paid out to the plotholders as a monthly salary over next four months.

\section{REFERENCES}

[1] Hirschman AO. The strategy of economic development. New York: Yale University Press 1960.

[2] Brinkman R. Economic growth $v s$ economic development: toward a conceptual clarification. J Econ Issues 1995; 29(4): 1171-218.

[3] Bromley DW. Improving irrigated agriculture: institutional reform and the small farmer. World Bank staff working paper number 531. Washington, D.C.: The World Bank 1982.

[4] Ostrom E. Governing the commons: the evolution of institutions for collective action: political economy of institutions and decisions. New York: Cambridge University Press 1990.

[5] North DC. Institutions, Institutional Change, and Economic Performance. M.A. Cambridge: Cambridge University Press 1990.

[6] Mbatha $\mathrm{CN}$, Antrobus GG. Institutions and economic research: a case of location externalities on agricultural resource allocation in the Kat river basin, South Africa. Agrekon 2008; 47(4): 470-94.

[7] Williamson $\mathrm{O}$. The new Institutional economist: taking stock, looking ahead. J Econ Lit 2000; 38(3): 595-613.

[8] Oosthuizen LK, Meiring JA, Botha PW, Grove B, Monkhei MM, Pretorius I. Cost estimating procedures for micro, drip and furrow irrigation systems as well as economic analyses of the relevant irrigation systems for large and small scale farmers in the Onderberg/Nkomazi region: Water Research Commission (WRC) report number 974/1/05. Pretoria: The WRC 2005.

[9] KDOR. Kat dam operating rules: project number 13883. Bisho, Republic of Ciskei: Department of Public Works 1989.

[10] Lerotholi S. The role of salinity as an abiotic driver of ecological conditions in rural agricultural catchments. Masters Dissertation in Water Quality. Grahamstown: Rhodes University 2005.

[11] Vatn A, Bromley D. Externalities - a market model failure. J Environ Res Econ 1997; 9(2): 135-51.

[12] Myrdal G. Economic theory and under-developed regions. London: Duckworth 1957.

[13] Pollard S, Biggs H, du Toit D. Towards a socio-ecological systems view of the Sand River catchment, South Africa: an exploratory resilience analysis. Water Research Commission (WRC) report number TT 364/08. Pretoria: The WRC 2008.

[14] Eicher CK. Institutions and the African farmer. Third distinguished economist lecture at the International Maize and Wheat Improvement Centre (CIMMYT). Mexico City, Mexico 1999.

[15] Nel E. NGO-facilitated local economic development. Urban Forum 1998; 8(2): 277-93.
[16] DLA. Mpofu-Stockenstrom district land assessment project. East London: The Department of Land Affairs 1998.

[17] Motteux NMG. Evaluating people-environment relationships: developing appropriate research methodologies for sustainable management and rehabilitation of riverine areas by communities in the Kat river valley, Eastern Cape Province, South Africa. PhD Thesis in Geography. Grahamstown: Rhodes University 2002.

[18] Painter C. Personal communication of retired middle Kat irrigator and executive member of the Kat River Valley Irrigation Water Board. Fort Beaufort 2005.

[19] Water Act (54). Pretoria: Republic of South Africa. Government Gazette 861, 1956.

[20] Nel E, Hill T, Binns T. Development from below in the 'new' South Africa: the case of Hertzog, Eastern Cape. Geogr J 1997; 163(1): 57-64.

[21] Mbatha CN. A game theoretic perspective for enhanced stakeholder participation in integrated water resources management: a Kat river case study. Masters Dissertation in Environmental Economics. Grahamstown: Rhodes University 2005.

[22] Ntsebenza J. Personal communication of the former chairperson of Hacop (Fairbain Branch). Fairbain: Mpofu district 2006.

[23] Hacop. Hertzog agricultural cooperative meeting-workshop on the $20^{\text {th }}$ January. Fairbain: Mpofu district 2006.

[24] Binns T, Hill T, Nel, E. Learning from the people: participatory rural appraisal, geography and rural development in the 'new' South Africa. Appl Geogr 1997; 17(1): 1-9.

[25] Hacop. Hertzog agricultural cooperative meeting on $30^{\text {th }}$ November. Fairbain: Mpofu district 2004.

[26] Hacop. Hertzog agricultural cooperative operational procedures. Fairbain: Mpofu district 2005.

[27] Loets V. Personal communication of land chief planner in the provincial Department of Land Affairs. Port Elizabeth 2005.

[28] Mbatha CN. A case for institutional investigations in economic research methods with reference to South Africa's agricultural sector. PhD Thesis in Development Economics. Rhodes University 2007.

[29] DLA. The Hertzog irrigation business plan. East London: The Department of Land Affairs 2002.

[30] LRAD. Land Redistribution for Agricultural Development. Pretoria: The Department of Land Affairs 2005.

[31] NWA. The National Water Act Number 36 of 1998. Pretoria: Republic of South Africa Government Gazette 1998.

(C) Mbatha and Antrobus; Licensee Bentham Open.

This is an open access article licensed under the terms of the Creative Commons Attribution Non-Commercial License (http://creativecommons.org/licenses/by$\mathrm{nc} / 3.0 /$ ) which permits unrestricted, non-commercial use, distribution and reproduction in any medium, provided the work is properly cited. 